Coventry University and

The University of Wisconsin Milwaukee Centre for By-products Utilization,

Second International Conference on Sustainable Construction Materials and Technologies

June 28 - June 30, 2010, Università Politecnica delle Marche, Ancona, Italy.

Main Proceedings ed. J Zachar, P Claisse, T R Naik, E Ganjian. ISBN 978-1-4507-1490-7

http://www.claisse.info/Proceedings.htm

\title{
Microbial Concrete: A Way to Enhance Durability of Building Structures
}

\author{
Varenyam Achal $^{1}$, Abhijit Mukherjee ${ }^{2}$, and M. Sudhakara Reddy ${ }^{1}$ \\ ${ }^{1}$ Department of Biotechnology, ${ }^{2}$ Department of Civil Engineering; Thapar University, \\ Patiala, Punjab, India-147 004. E-mail: <achal@thapar.edu>, \\ <abhijit@thapar.edu>,<msreddy@thapar.edu>.
}

\begin{abstract}
Natural processes, such as weathering, faults, land subsidence, earthquakes, and human activities create fractures and fissures in concrete structures which can reduce the service life of the structures. A novel strategy to restore or remediate such structures is biomineralization of calcium carbonate using microbes such as Bacillus species. In the present study, Bacillus sp. CT-5, isolated from cement, was used to study compressive strength and water absorption tests. The results showed 36\% increase in compressive strength of cement mortar with the addition of bacterial cells. Calcite deposition on treated cubes absorbed nearly six times less water than the control cubes. The current work demonstrates that production of "microbial concrete" by Bacillus sp. on constructed facilities enhanced the durability of building materials.
\end{abstract}

\section{INTRODUCTION}

The requirements for high durability for structures exposed to harsh environments such as seafloor, offshore structures, tunnels, highway bridges, sewage pipes and structures for solid and liquid wastes containing toxic chemicals and radioactive elements may not be achieved using today's ordinary Portland cement (OPC). It is generally accepted that the durability of concrete is related to the characteristics of its pore structure [Khan 2003]. Degradation mechanisms of concrete often depend on the way potentially aggressive substances can penetrate into the concrete, possibly causing damage. The permeability of the concrete is depending on the porosity and on the connectivity of the pores. The more open the pore structure of the concrete, the more vulnerable the material is to degradation mechanisms caused by penetrating substances. The deterioration of concrete structures usually involves movement of aggressive gases and/or liquids from the surrounding environment into the concrete followed by physical and/or chemical reactions within its internal structure, possibly leading to irreversible damage [Claisse et al. 1997]. Therefore, transport properties and mechanical properties (compressive strength) are the important factors for concrete durability.

Recently, microbiologically induced calcium carbonate precipitation (MICCP) resulting from metabolic activities of some specific microorganisms in concrete to improve the overall behavior of concrete has begun to attract interest of researchers. Previous studies with aerobic microorganism (Bacillus pasteurii and Pseudomonas aeruginosa) showed a significant improvement (about 18\%) in compressive strength of cement mortar [Ramakrishnan et al. 1998; Ramachandran et al. 2001]. 
MICCP comprises of a series of complex biochemical reactions [Stocks-Fischer et al. 1999]. As part of metabolism, some bacterial species produce urease, which catalyzes urea to produce $\mathrm{CO}_{2}$ and ammonia, resulting in an increase of $\mathrm{pH}$ in the surroundings where ions $\mathrm{Ca}^{2+}$ and $\mathrm{CO}_{3}{ }^{2-}$ precipitate as $\mathrm{CaCO}_{3}$. Possible biochemical reactions in medium to precipitate $\mathrm{CaCO}_{3}$ at the cell surface that provides a nucleation site can be summarized as follows.

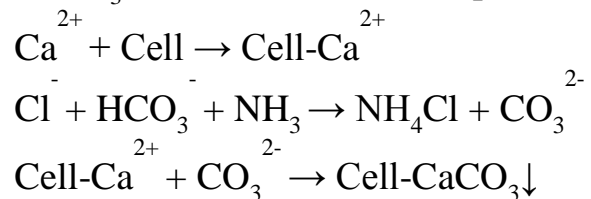

A novel technique for the remediation of damaged structural formations has been developed by employing a selective microbial plugging process in which microbial metabolic activities promote precipitation of calcium carbonate in the form of calcite [Gollapudi et al. 1995]. As a microbial sealant, $\mathrm{CaCO}_{3}$ exhibited its positive potential to selectively consolidate simulated fractures and surface fissures in granites and sand plugging [Zhong and Islam 1995; Achal et al. 2009a].

The present work deals with the compressive strength and concrete permeability using water absorption test, which are the most important parameters influencing the durability of concrete and finally its performance. In this paper, the effect of bacteria isolated from cement, on the compressive strength and water permeability of cement mortar was investigated.

\section{MATERIALS AND METHODS}

\section{Materials}

Ordinary Portland Cement conforming to IS 12269-1987 was used. Locally available clean, well-graded, natural river sand having fineness modulus of 2.89 conforming to IS 383-1970 was used as fine aggregate.

\section{Microorganism}

Bacillus sp. CT-5, isolated from commercially available cement, was used in this study. The culture was routinely maintained on Nutrient agar $(\mathrm{pH} 8.0)$ medium. Nutrient broth-urea (NBU) medium ( $8 \mathrm{~g}$ nutrient broth, $2 \%$ urea and $25 \mathrm{mM} \mathrm{CaCl}_{2}$ ) was used to grow the isolate. Filter-sterilized urea and $\mathrm{CaCl}_{2}$ was added into nutrient broth medium. Details of NBU medium content and preparation were published previously [Achal et al., 2009a]. Bacterial culture was grown at $37^{\circ} \mathrm{C}$ under shaking condition $(130 \mathrm{rpm})$.

\section{Compressive strength test}

To study the compressive strength test of cement mortar, Bacillus sp. CT-5 was grown in NBU media. The cement to sand ratio was 1:3 (by weight), and the bacterial culture/water to cement ratio was 0.47 . A cube mould of $70.6 \mathrm{~mm}$ was used, as per IS 4031-1988. Sand and cement were thoroughly mixed, adding along with grown culture of Bacillus sp. CT-5 correspondence to the optical density $(600 \mathrm{~nm})$ of 1.0 . Cubes were cast and compacted in a vibration machine. After de-molding, all specimens were cured in NBU medium at room temperature until compression testing at the intervals of 3,7 and 28 days. Control specimens were also prepared in similar way where water and NBU medium replaced bacterial culture. Compression testing was performed using automatic compression testing machine, COMPTEST 3000. 


\section{Water absorption test}

To determine the increase in resistance towards water penetration a sorptivity test, based on the RILEM 25 PEM (II-6), was carried out. The mortar specimens were coated at the four edges adjacent to the treated side, to ensure unidirectional absorption through the treated side. After coating, the test cubes were dried at $45^{\circ} \mathrm{C}$ in a ventilated oven, establishing a mass equilibrium of less than $0.1 \%$ between two measurements at 24 hour intervals. The specimens were then exposed, to $10 \pm 1 \mathrm{~mm}$ of water, with the treated side facing downwards (water level about $2 \mathrm{~mm}$ above the base of the specimen). At regular time intervals (15 min, $30 \mathrm{~min}$; $1 \mathrm{~h}$, $1.5 \mathrm{~h}, 3 \mathrm{~h}, 5 \mathrm{~h}, 8 \mathrm{~h}, 24 \mathrm{~h}, 72 \mathrm{~h}, 96 \mathrm{~h}, 120 \mathrm{~h}, 144 \mathrm{~h}$ and $168 \mathrm{~h})$ the specimens were removed from the water and weighed, after drying the surface with a wet towel. Immediately after the measurement the test specimens were submerged again. The sorptivity coefficient, $\mathrm{k}\left[\mathrm{cm} . \mathrm{s}^{-}\right.$ ${ }^{1 / 2}$ ], was obtained by using the following expression:

$\mathrm{Q} / \mathrm{A}=\mathrm{k} \sqrt{\mathrm{t}}_{\mathrm{t}}$

where $\mathrm{Q}$ is the amount of water absorbed $\left[\mathrm{cm}^{3}\right]$; $\mathrm{A}$ is the cross section of the specimen that was in contact with water $\left[\mathrm{cm}^{2}\right]$; $\mathrm{t}$ is the time [s], Q/A was plotted against the square root of time, then $\mathrm{k}$ was calculated from the slope of the linear relation between the former.

\section{RESULTS AND DISCUSSION}

\section{Compressive strength test}

Figure 1 summarizes the 3, 7 and 28 day compressive strength of different cement mortar specimens. The compressive strength had significantly increased for the mortar cubes that contained microbial cells. The highest compressive strength was obtained with mortar cubes prepared with Bacillus sp. CT-5 that were incubated for 28 days ( $31 \mathrm{MPa}$ ) as compare to those prepared with water $(23 \mathrm{MPa})$ and NBU medium $(24 \mathrm{MPa})$. There was $36.15 \%$ improvement in the compressive strength of mortar specimens at 28 days, prepared with bacterial cells compared to control. It is noteworthy that, among the control groups without cells, the cubes cured in microbial growth medium were stronger than those cured in water although there was not significant difference. The ionic strength of medium containing Urea$\mathrm{CaCl}_{2}$ appeared to enhance the strength of the mortar cubes.

The improvement in compressive strength by Bacillus sp. CT-5 is probably due to deposition of $\mathrm{CaCO}_{3}$ on the microorganism cell surfaces and within the pores of cement-sand matrix, which plug the pores within the mortar [Ramakrishnan et al. 1998; Ramachandran et al. 2001; Ghosh et al. 2005; Achal et al. 2009a].

To determine whether the increase in compressive strength of the specimens prepared with bacteria could be attributed to the microbial calcite precipitation, the mortar samples were taken off and examined under SEM. Figure $2 \mathrm{a}$ is a scanning electron micrograph of the matrix of bacteria-free cement mortar while Fig. $2 b$ shows micrographs of the specimen prepared with Bacillus sp. CT-5. The sample showed calcite crystals grown all over and precipitated with rod shaped structures (typical shape of Bacillus species). They had distinct and sharp edges, indicating a full growth of the crystals. We previously reported and observed rod shaped structure of Sporosarcina pasteurii which helped in calcite precipitation in sand column [Achal et al. 2009b].

There was no significant improvement in compressive strengths at 3 and 7 days of mortar cubes with all media. The overall trend of an increase in compressive strength up to 28 days might be attributed to the behavior of microbial cells within the cement mortar matrix. During the initial curing period, microbial cells obtained good nourishment, because the cement 
mortar was still porous; but growth was not proper as there was completely new environment for microbes. It is also possible that as the $\mathrm{pH}$ of the cement remained high, cells were in inactive condition and as curing period was increased, it started growing slowly. Upon cell growth, calcite would precipitate on the cell surface as well as within the cement mortar matrix which might be also attributed by the various ions present in media. Thus, the cement mortar became less porous and permeable. Once many of the pores in the matrix were plugged, the flow of the nutrients and oxygen to the bacterial cells stopped, eventually the cells either died or turned into endospores and acted as an organic fiber, increasing the compressive strength of the mortar cubes. This explains the behavior of the increased compressive strength at 28 days in cement mortar cubes prepared with microbial cells. The increase in the matrix strength (for concrete made with bacterial cells) would have resulted in lesser mean expansion and would have eventually increased the overall durability performance of the concrete [Ramakrishnan et al. 2001]. Thus it was concluded that the increase in compressive strengths is mainly due to consolidation of the pores inside the cement mortar cubes with microbiologically induced calcium carbonate precipitation.

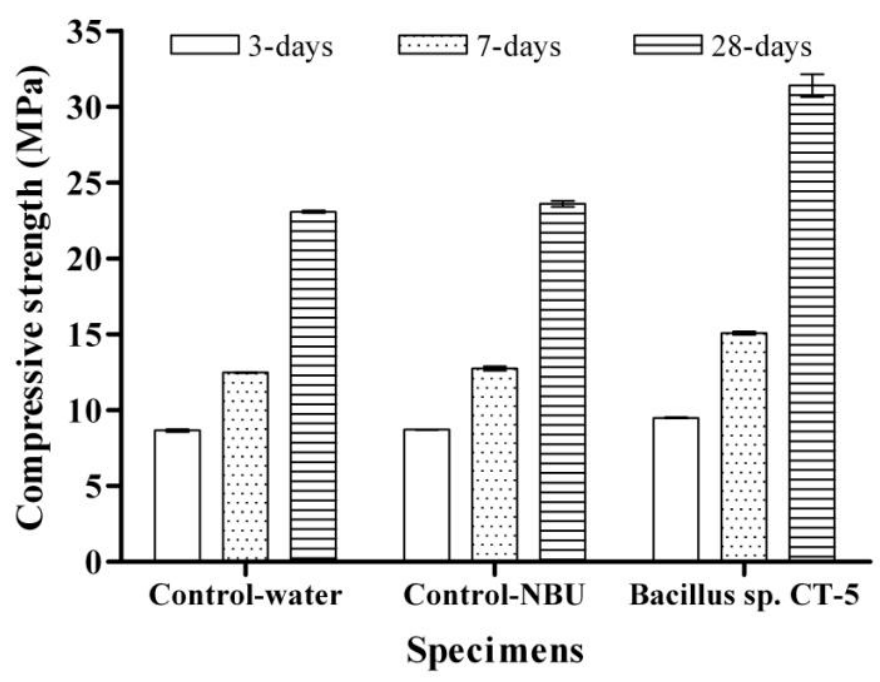

Fig. 1. Effect of CT-5 on the Compressive Strength of Cement Mortar Cubes at 3, 7 and 28 days Prepared with w/c ratio 0.47. (In control-NBU and Bacillus sp. CT-5 Treatments, Water is Replaced with Media and Media with Bacterial cells respectively 

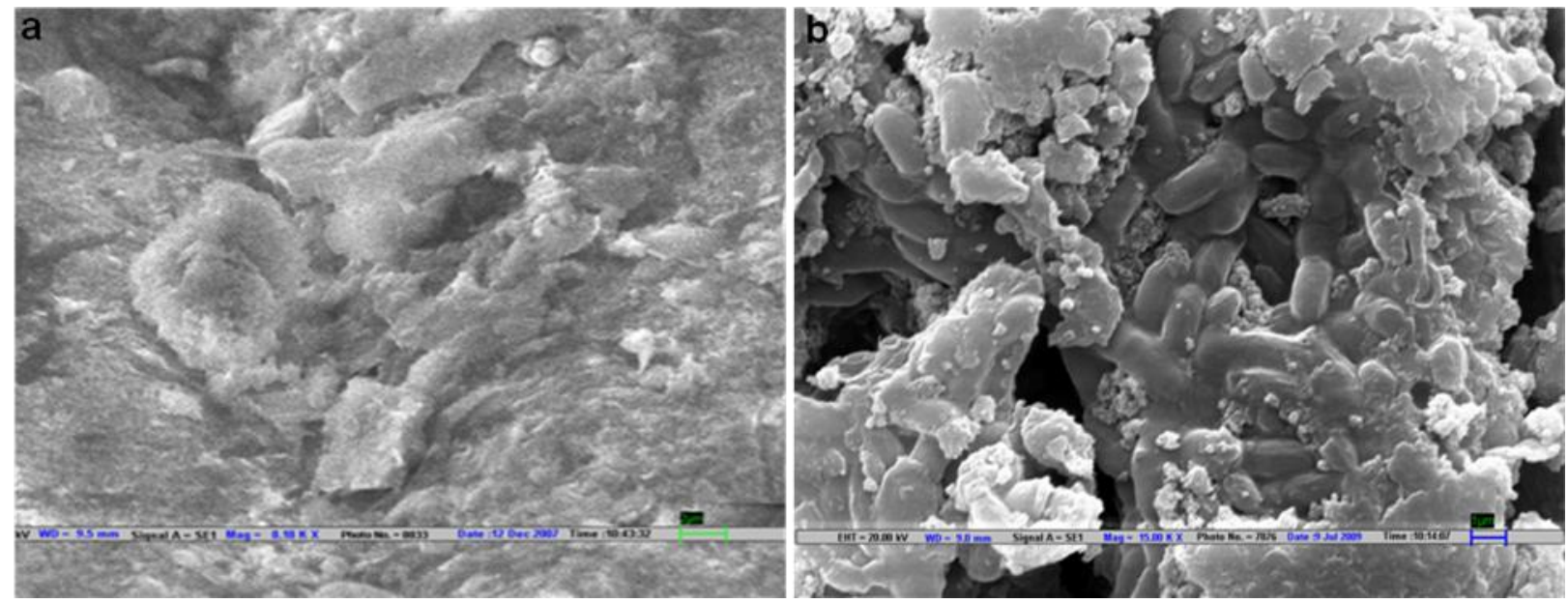

Fig. 2. Scanning Electron Micrographs of Cement Mortar Specimens. (a) Matrix of Cement Mortar Prepared without Bacteria, and (b) Showing Dense Calcite Precipitation as Calcite Crystals with Rod Shaped Impressions Housed by Bacillus sp. CT-5

\section{Water absorption test}

Fig. 3 shows the influence of the surface treatment on the water absorption rate for mortar cubes with a w/c 0.47. Over a period of 168 hours the cubes treated with Bacillus sp. CT-5 absorbed nearly six times less water than the control cubes. The presence of bacteria resulted in a significant decrease of the water uptake compared to untreated specimens (control).

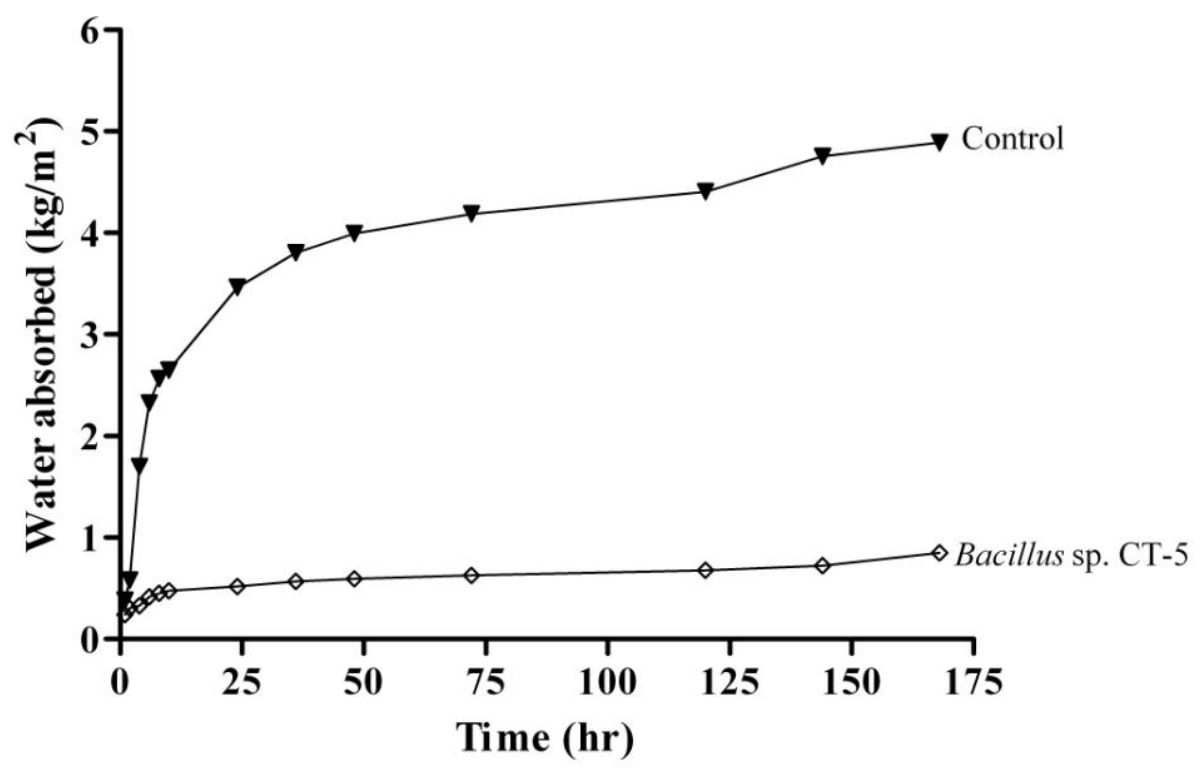

Fig. 3. The Influence of the Bacterial Treatment on the Rate of Water Absorption Versus Time for Mortar Cubes

The decrease in permeability of mortar specimens treated with bacteria could be seen from the water absorption experiment. The deposition of a layer of calcium carbonate crystals on 
the surface resulted in a decrease of the permeation properties. As a consequence, the ingress of harmful substances may be limited. Nemati and Voordouw [2003] noticed a decrease of the permeability of sandstone cores after injecting $\mathrm{CaCO}_{3}$ forming reactants. From this experiment, it is clear that the presence of a layer of carbonate crystals on the surface by bacterial isolate has the potential to improve the resistance of cementitious materials towards degradation processes.

\section{CONCLUSION}

The significance of this research is the use of urease producing bacterial isolates like Bacillus species in remediation of concrete. The study has identified the positive effect of Bacillus sp. CT-5 on the compressive strength of Portland cement mortar cubes and increased its strength. Furthermore, an increase in resistance towards water penetration has been made to evaluate the performance of bacterial isolate. The development of the "Microbial Concrete" will provide the basis for an alternative and high quality concrete sealant that is cost effective and environmentally safe and ultimately lead to enhancement in the durability of building materials.

\section{REFERENCES}

Achal, V., Mukherjee, A., Basu, P. C., and Reddy, M. S. (2009a). "Lactose mother liquor as an alternative nutrient source for microbial concrete production by Sporosarcina pasteurii." Journal of Industrial Microbiology and Biotechnology, 36, 433-438.

Achal, V., Mukherjee, A., Basu, P. C., and Reddy, M. S. (2009b). "Strain improvement of Sporosarcina pasteurii for enhanced urease and calcite production." Journal of Industrial Microbiology and Biotechnology, 36, 981-988.

Claisse, P. A., Elsayad, H. A., and Shaaban I. G. (1997). "Absoprtion and sorptivity of cover concrete." Journal of Materials in Civil Engineering, 9, 105-110.

Ghosh, P., Mandal, S., Chattopadhyay, B. D., Pal, S. (2005). "Use of microorganism to improve the strength of cement mortar." Cement and Concrete Research, 35, 19801983.

Gollapudi, U. K., Knutson, C. L., Bang, S. S., and Islam, M. R. (1995). "A new method for controlling leaching through permeable channels." Chemosphere, 30, 695-705.

Khan, M. I. (2003). "Isoresponses for strength, permeability and porosity of high performance Mortar." Building and Environment, 38, 1051-1056.

Nemati, M., and Voordouw, G. (2003). "Modification of porous media permeability, using calcium carbonate produced anzymatically in situ." Enzyme Microbial Technology, 33, 635-642.

Ramachandran, S. K., Ramakrishnan, V., and Bang, S. S. (2001). "Remediation of concrete using microorganisms." American Concrete Institute Materials J., 98, 3-9.

Ramakrishnan, V., Bang, S. S., and Deo, K. S. (1998). "A novel technique for repairing cracks in high performance concrete using bacteria." Proc. Int. conf. on high performance high strength concrete, Perth, Australia, 597-618.

Stocks-Fischer, S., Galinat, J. K., and Bang, S. S. (1999). "Microbiological precipitation of $\mathrm{CaCO}_{3}$." Soil Biology and Biochemestry, 31, 1563-1571.

Zhong, L., and Islam, M. R. (1995). "A new microbial process and its impact on fracture remediation." 70 Annual Technical Conference and Exhibition of the Society of Petroleum Engineers, Oct 22-25, Dallas, Texas. 